\title{
Variation in energy density of Loricariichthys platymetopon (Siluriformes: Loricariidae) in the upper Paraná River basin
}

\author{
Daniela Aparecida Garcia and Evanilde Benedito
}

The present study described the variations in energy density from skeletal muscles of Loricariichthys platymetopon in relation to body size, sex, gonadal development stages, sampling site and habitat type (lotic, semi-lotic and lotic). Samplings were performed between June 2002 and August 2006 in points located in the upper Paraná River floodplain, Rosana Reservoir and Diamante Stream. The energy density from each muscle sample of 212 specimens was determined using an adiabatic calorimeter. The correlations between the variables 'muscle energy density' and 'specimen standard length' were not significant. Only in the Rosana Reservoir there was a significant difference in energetic means between 'sex'. Otherwise, due to the gonadal development stage, a significant difference between energetic means was recorded only for males from the upper Paraná River floodplain and for both sexes in Rosana Reservoir. The density of muscle energy ranged from 4,170 to 5,540 cal/g DW (dry weight), with the means ( \pm standard deviation) of 5,140 $0.06 \mathrm{cal} / \mathrm{g} \mathrm{DW}$ in the Reservoir, $4,950 \pm 0.25 \mathrm{cal} / \mathrm{g}$ DW in the stream and $4,920 \pm 0.18 \mathrm{cal} / \mathrm{g} \mathrm{DW}$ in the floodplain. Furthermore, we also detected a significant difference between the energy means from the different sampled sites, but the same was not registered among the analyzed habitats. In conclusion, the variation in muscle energy density from L. platymetopon may occur. The occurrence of variation between the sexes depends on the site, and the density variation among the stages depends on both the site and 'sex'. In summary, the spatial variation in muscle energy density from this species strengthens the idea that this factor is not a constant parameter, so it should not be applied in bioenergetics modeling and in the quantification of energetic balance as an unique value.

O presente estudo objetivou descrever as variações na densidade de energia dos músculos estriados esqueléticos de Loricariichthys platymetopon em relação aos fatores tamanho, sexo, estádio de desenvolvimento gonadal, local e tipo de habitat (lótico, semi-lótico e lótico). As amostragens foram realizadas entre junho de 2002 e agosto de 2006 em pontos localizados na planície alagável do alto rio Paraná, no reservatório de Rosana e no ribeirão Diamante. A densidade de energia de cada amostra de músculo de 212 espécimes de L. platymetopon foi determinada utilizando-se bomba calorimétrica. As correlações entre as variáveis 'densidade de energia muscular' e 'comprimento padrão do espécime' não foram significativas. Diferença significativa entre as médias energéticas foi registrada entre 'sexo' apenas no reservatório de Rosana. Diferença nas médias energéticas, devido ao estádio de desenvolvimento gonadal, foi significativa somente para machos na planície alagável do alto rio Paraná e para ambos os sexos no reservatório de Rosana. A densidade de energia muscular variou de 4.170 a $5.540 \mathrm{cal} / \mathrm{g}$ PS (peso seco), sendo as médias ( \pm desvio-padrão) igual a $5.140 \pm 0,06 \mathrm{cal} / \mathrm{g}$ PS no reservatório, $4.950 \pm 0,25 \mathrm{cal} / \mathrm{g}$ PS no ribeirão e $4.920 \pm 0,18 \mathrm{cal} /$ g PS na planície. Foi encontrada diferença significativa entre as médias de energia dos diferentes locais amostrados, entretanto, o mesmo não foi registrado nos habitats analisados. Conclui-se que pode ocorrer variação na densidade de energia muscular de L. platymetopon. A ocorrência de variação entre os sexos depende do local de coleta, e a variação na densidade entre os estádios depende tanto do local quanto do 'sexo'. A variação espacial na densidade de energia muscular desta espécie reforça a idéia de que a mesma não é um parâmetro invariável e que por isso não deve ser aplicada na modelagem bioenergética e na quantificação do balanço energético como um valor único.

Key words: Calorimetry, Detritivorous fish, Body size, Gonadal maturation, Habitat.

Nupelia/DBI, Programa de Pós-Graduação em Ecologia de Ambientes Aquáticos Continentais, Universidade Estadual de Maringá. Av. Colombo, 5790, 87020-900 Maringá, PR, Brazil. eva@nupelia.uem.br (EB) 


\section{Introduction}

Determining the energy density of biological materials, as well as identifying the factors related to their variability, are important actions for bioenergetics modeling and to investigate the energy balance of species (Hansen et al., 1993; Pedersen \& Hislop, 2001; Dourado \& Benedito-Cecilio, 2005).

Energy density is subject to multifactor influence, and due to the scarcity of data on this subject for several species, some studies have assumed uniques values (Economidis et al., 1981; Hansen et al., 1993; Pedersen \& Hislop, 2001; Dourado \& Benedito-Cecilio, 2005). This action is viewed as inadequate by some authors, as significant differences - both intra- and interspecific - have been detected at temperate and Neotropical environments (Bryan et al., 1996; Paul et al., 1998; Pedersen \& Hislop, 2001; Vismara et al., 2004; Santos et al., 2006).

The species considered for this study is Loricariichthys platymetopon Isbrücker \& Nijssen, 1979, known popularly as acari, cari, rapa-canoa, cascudo-viola or cascudo-chinelo. It belongs to the Loricariidae family, which features the greatest number of species among siluriforms in the Neotropical region (Reis et al., 2003).

Studies on the biology of this species in the Paraná River (Dei Tos et al., 1997) and in the Uruguay River basin (Querol et al., 2002) indicate that L. platymetopon inhabits mainly lentic and semi-lotic habitats, and that its reproductive period extends from October to March (Spring-Summer) (Vazzoler, 1996; Marcucci et al., 2005). In the upper Paraná River flood- plain and in the Diamante Stream this species was considered the most abundant (Gaspar da Luz et al., 2004; Luiz et al., 2005; Morales et al., 2009b).

Loricariichthys platymetopon is a detritivorous species, feeding on detritus and benthic organisms (Fugi et al., 2001). Because of its feeding habits and abundance, this species plays an important role in nutrient and energy cycling in Neotropical ecosystems.

Therefore, the objective of this study is to describe the variations in energy density of the skeletal muscles of $L$. platymetopon in relation to factors that can influence it, including body size, sex, gonadal development stages, site and sampling habitat type, in order to investigate whether it is possible or not to use energy density for a species as an invariable parameter in bioenergetic modeling and in the quantification of energetic balance.

\section{Material and Methods}

This study involved the following sampling sites and periods in the upper Paraná River basin: a stretch of the upper Paraná River floodplain (FP), where five points were sampled in November 2002, March and September 2003; at the lentic point of the Rosana Reservoir (RR), sampled in June and December 2002; and at three points of the Diamante Stream (DS), sampled in November 2005, February, May and August 2006 (Fig. 1). The description of the sampled sites is available in Vazzoler et al. (1997), Rodrigues et al. (2005), and Morales et al. (2009a).

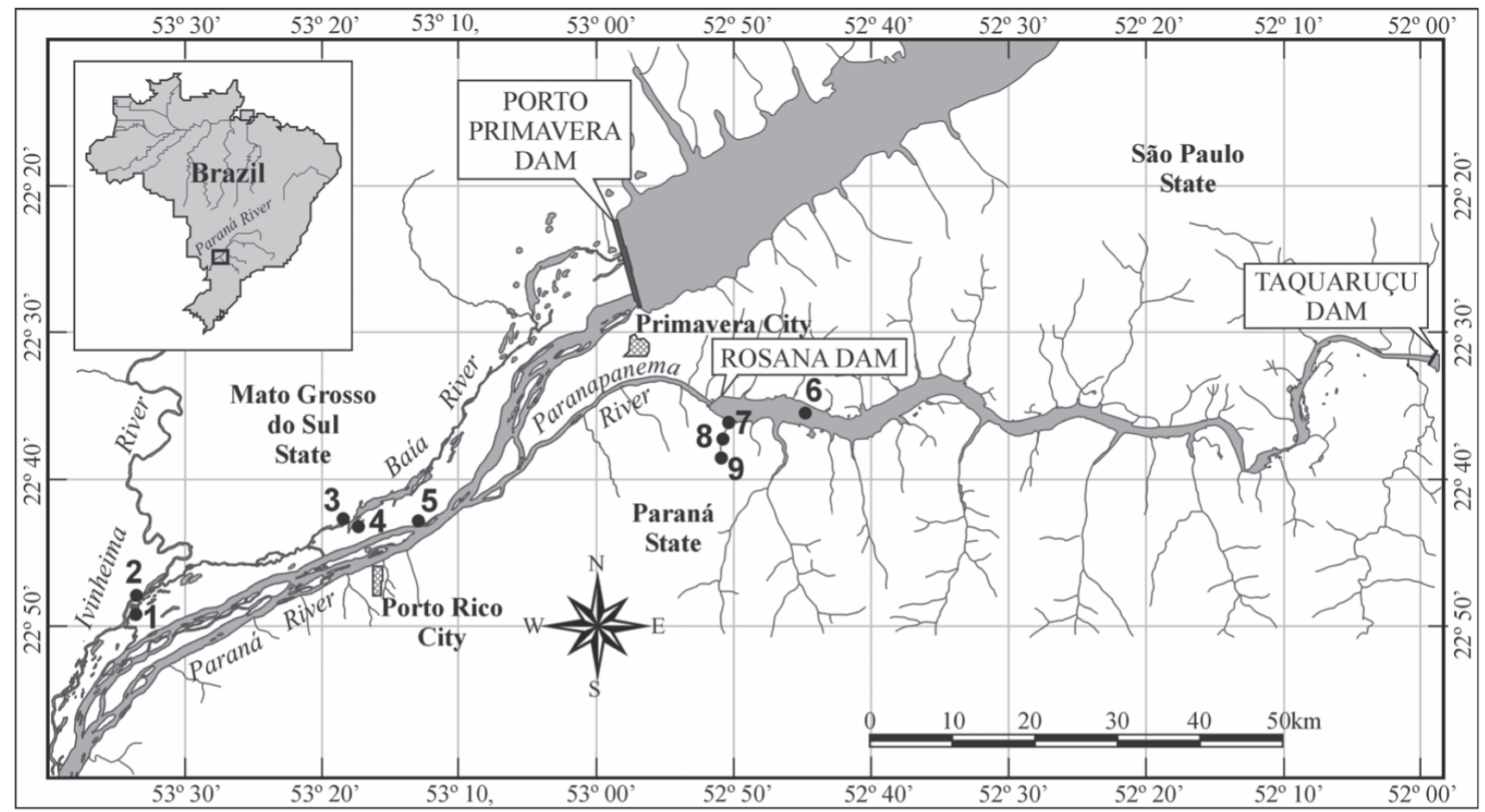

Fig. 1. Study area and location of the sampled points in the upper Paraná River floodplain (1- Patos Lake; 2- Ivinheima River; 3Baia River; 4- Guaraná Lake; 5- Garças Lake; Patos Lake; 2- Ivinheima River; 3- Baia River; 4- Guaraná Lake; 5- Garças Lake; Rosana Reservoir (6) and Diamante Stream (7, 8 e 9). Number of specimens by sampling site: $\mathrm{n}_{1}=31, \mathrm{n}_{2}=19, \mathrm{n}_{3}=15, \mathrm{n}_{4}=12, \mathrm{n}_{5}=$ $5, \mathrm{n}_{6}=56, \mathrm{n}_{7}=35, \mathrm{n}_{8}=22$ and $\mathrm{n}_{9}=17$. 
The sampled point at the Rosana Reservoir was considered a lentic habitat. In the Diamante Stream, the point nearest the riverhead was classified as lotic, the intermediate point was semi-lotic, and the point closest to the Rosana Reservoir was deemed lentic. In the upper Paraná River floodplain, the Ivinheima River was classified as lotic, the Baia River was semi-lotic, and the floodplain lakes were considered lentic.

At each sampled point, gillnets of various mesh sizes (from 2.4 to $16 \mathrm{~cm}$ between adjacent nodes) were exposed for 24 hours, and inspected every eight hours. Each specimen was measured (standard length - mm), and its sex and gonadal development stage were determined. The stages considered were: immature (IMT), resting (RES), beginning of maturation (BMA), maturing (MAG), mature (MAT), semi-spent (SSP), spent (SPE), recovery (REC) (adapted from Vazzoler, 1996).

Muscle samples were extracted from the lateral region near the dorsal fin. The samples were then washed in distilled water and enclosed in aluminum foil, labeled and frozen. They were later dried in a greenhouse using forced ventilation $\left(60^{\circ} \mathrm{C}\right.$, $48 \mathrm{~h}$ ) and macerated using a ball mill. The energy density of these samples (calories per gram of dry weight) was determined using an adiabatic calorimeter (Parr 1261).

The voucher specimens were deposited in the Museu Ictiológico do Núcleo de Pesquisa em Limnologia, Ictiologia e Aquicultura (NUPELIA), at the Universidade Estadual de Maringá (upper Paraná River floodplain - NUP 2568 and NUP 445; Rosana Reservoir and Diamante Stream - NUP 2799).

The variation (increase or decrease) on muscle energy density of L. platymetopon related to the increase in body size from the specimen (standard length) was investigated using a non-parametric correlation analysis (Kendall tau rank correlation), separated by site and sex. Computer software STATISTICA (version 7.1) was used for this analysis, and correlation values of $p \leq 0.05$ were considered significant.

In order to verify whether the mean energy density differed according to sex, gonadal development stages, site and habitat type, non-parametric unifactorial analyses of variance (One-way ANOVA test) were conducted $(5,000$ randomizations, ECOSIM) (Gotelli \& Enstminger, 2006). A significance level of $\alpha=0.05$ was adopted using the Bonferroni correction, with $\mathrm{p}=0.0083$.

In the analysis between the sexes, only specimens whose gonadal development stages were equivalent to both males and females and among all three sampled sites were used (resting and spent). Conversely, in the analysis of the stages of gonadal development, all sampled specimens were used, separated by site and sex. The existence of spatial variation in caloric density was investigated by considering, firstly, specimens from both sexes belonging to the 'spent' and 'resting' stages of gonadal development, and later, all sampled specimens. Differences in energy density, due to type of habitat (lentic, semi-lotic and lotic), were investigated in the floodplain and stream; specimens from both sexes were used in that analysis, with stages of gonadal development equivalent to the three habitats of the floodplain (resting) and stream (spent).
Table 1. Correlation analysis between standard length and energy density of female (F) and male (M) Loricariichthys platymetopon in the upper Paraná River floodplain (FP), Rosana Reservoir (RR) and Diamante Stream (DS). Number of specimens sampled (n), mean \pm standard deviation (Mean $\pm \mathrm{SD}$ ), range of standard length, values of the Kendall-tau $(\tau)$ correlation coefficient. For all correlations presented $\mathrm{p}>0.05$.

\begin{tabular}{ccccc}
\hline Site/Sex & $\mathrm{n}$ & Mean \pm SD $(\mathrm{mm})$ & Range $(\mathrm{mm})$ & $\tau(\mathrm{p}>0.05)$ \\
\hline $\mathrm{FP} / \mathrm{F}$ & 45 & $220.6 \pm 4.17$ & $140-302$ & -0.02 \\
$\mathrm{FP} / \mathrm{M}$ & 37 & $211.1 \pm 3.22$ & $165-252$ & 0.17 \\
$\mathrm{RR} / \mathrm{F}$ & 31 & $202.1 \pm 5.56$ & $140-257$ & 0.19 \\
$\mathrm{RR} / \mathrm{M}$ & 25 & $187.9 \pm 3.18$ & $136-228$ & -0.05 \\
$\mathrm{DS} / \mathrm{F}$ & 36 & $207.9 \pm 3.02$ & $156-244$ & -0.01 \\
$\mathrm{DS} / \mathrm{M}$ & 38 & $204.2 \pm 1.88$ & $180-230$ & 0.06 \\
\hline Total & 212 & & & \\
\hline
\end{tabular}

\section{Results}

A total of 212 specimens of L. platymetopon was sampled, with 82 coming from the upper Paraná River floodplain, 56 from the Rosana Reservoir, and 74 from Diamante Stream. The sampled number, mean standard length, and the range in the body size of the specimens, according to site and sex, are shown on Table 1 . The correlations between the variables 'muscle energy density' and 'specimen standard length' were not significant for any of the sampled sites, for either sex (Table 1).

Only at Rosana Reservoir there was a significant difference in the mean energy density between the sexes (Floodplain: d.f. $=1, \mathrm{~F}=0.36, \mathrm{p}=0.55, \mathrm{n}_{\text {(females) }}=16$ and $\mathrm{n}_{\text {(males) }}=19$; Rosana Reservoir: d.f. $=1, \mathrm{~F}=14.68, \mathrm{p}=0.0008$, $\mathrm{n}_{\text {(females) }}=16$ and $\mathrm{n}_{\text {(males) }}=12$; Diamante Stream: d.f. $=1, \mathrm{~F}=$ $1.87, \mathrm{p}=0.18, \mathrm{n}_{\text {(females) }}=19$ and $\mathrm{n}_{\text {(males) }}=34$ ). In this Reservoir, males featured higher mean energy density than females $\left(\right.$ mean $\pm \mathrm{SD}_{\text {(males) }}=5,160 \pm 0.015 \mathrm{cal} / \mathrm{gDW} ;$ mean $\pm \mathrm{SD}_{\text {(females) }}=$ $5,140 \pm 0.015 \mathrm{cal} / \mathrm{gDW})$.

The difference in mean energy, due to the stage of gonadal development, was significant only for males in the upper Paraná River floodplain and for both sexes at the Rosana Reservoir. No significant difference was recorded for the Diamante Stream (Fig. 2).

Spatial variation was observed for energy density, with significant difference among the mean values of reservoir, stream and floodplain samples (Figs. 3a-b). Energy density varied between 4,170 and $5,540 \mathrm{cal} / \mathrm{g}$ DW.

Analyzing the habitats (lentic, semi-lotic and lotic) within the floodplain and stream locations, no significant differences were identified in the energy density (Figs. 4a-b).

\section{Discussion}

Factors that influence energy allocation in fish can be classified as biotic and abiotic. Interaction factors (competition, predation, parasitism) or factors inherent to the organism (sex, gonadal maturation stage, reproductive activity, age, body size) are considered biotic, while those linked to climate, food resource availability, as well as physical 

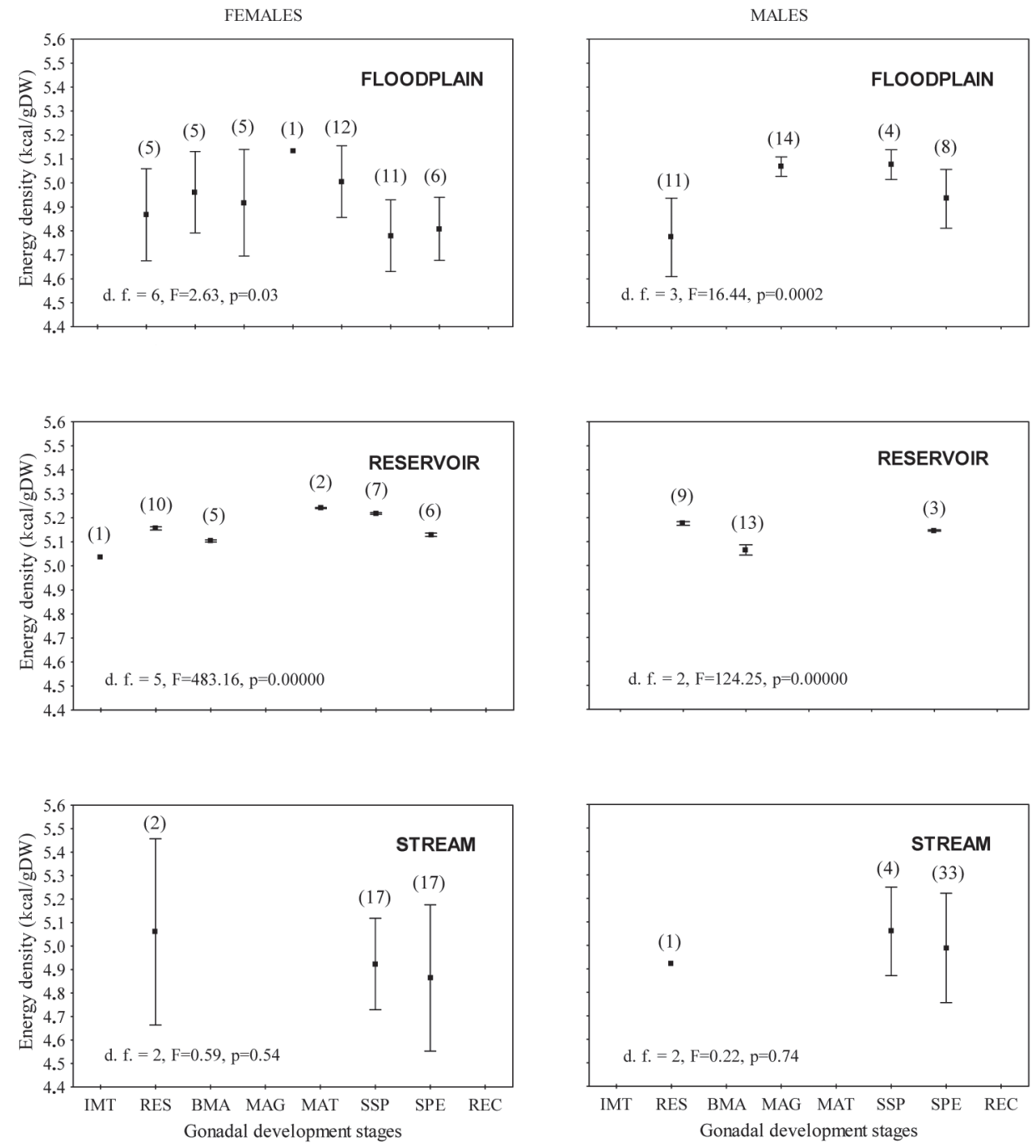

Fig. 2. Mean \pm standard deviation for muscle energy density of Loricariichthys platymetopon, at different gonadal development stages (immature $=\mathrm{IMT}$; resting $=\mathrm{RES}$; beginning of maturation $=\mathrm{BMA}$; maturing $=\mathrm{MAG}$; mature $=\mathrm{MAT}$; semi-spent $=\mathrm{SSP}$; spent $=$ SPE; recovery $=$ REC), in the upper Paraná River floodplain, Rosana Reservoir and Diamante Stream. Number of specimens between parentheses. One-way ANOVA are presented for each case.

and chemical aspects of water (flow speed, $\mathrm{pH}$, oxygen, salinity and temperature) are classified as abiotic (Dourado \& Benedito-Cecilio, 2005).

In the present study, the variation (increase or decrease) in muscle energy density from $L$. platymetopon related to the increase in specimen body size was not detected, since the correlation between these two variables was not significant. However, we expected to find a direct relationship between the increase in energy and the specimens body size as observed by Paul et al. (1998) studying juveniles and adults of Clupea pallasi. It is emphasized that the majority of analyzed $L$. platymetopon specimens were larger than the estimated size of first gonadal maturation $\left(\mathrm{L}_{50}=144 \mathrm{~mm}\right.$, according to Vazzoler, 1996). It is possible that, if a higher number of (juvenile-immature) smaller specimens had been sampled, a positive correlation between standard length and muscle energy density could have been recorded.
Regarding biotic factor 'sex', significant difference in energy density between $L$. platymetopon males and females was found only at the Rosana Reservoir, where males displayed higher mean energy density than females. No difference between males and females was observed in other studies, at the Manso Reservoir and adjacent area (State of Mato Grosso, Central Brazil), for tropical fish species Serrassalmus marginatus, S. maculatus, Brycon hilarii (Characidae) e Hypophthalmus edentatus (Hypophthalmidae) (Santos et al., 2006; Monteiro et al., 2007).

The results of the present study and those of Santos et al. (2006) and Monteiro et al. (2007) allow hypothesizing that "in tropical fish species, differences in muscle energy density between male and female specimens cannot be detected when using all gonadal development stages in the statistical analysis". The significant difference and higher mean energy for males of $L$. platymetopon recorded in the 


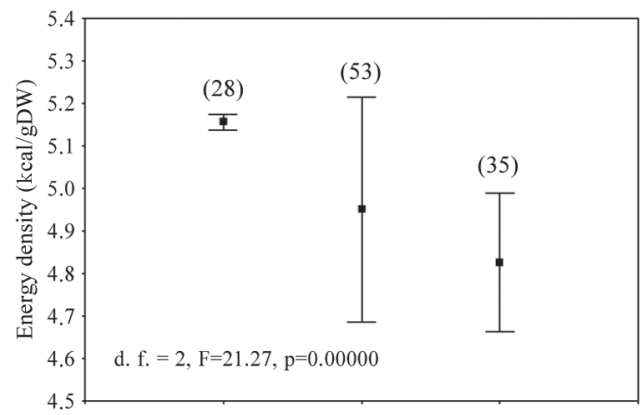

a

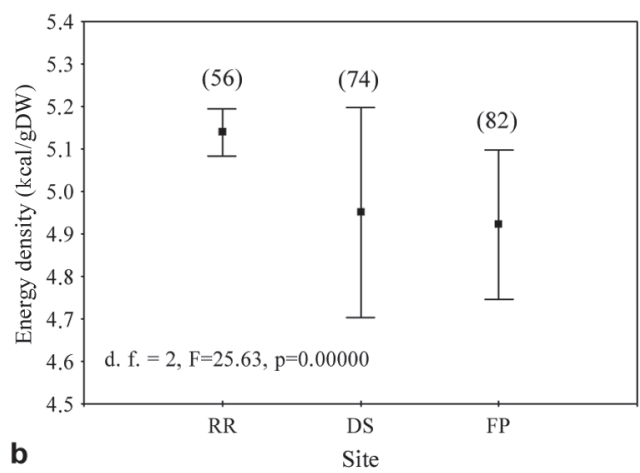

Fig. 3. Mean \pm standard deviation for muscle energy density of Loricariichthys platymetopon of both the sexes and same gonadal development stages (spent and resting) (a) and for both sexes and all stages sampled in the Rosana Reservoir (RR), Diamante Stream (DS) and upper Paraná River floodplain (FP) (b). Number of specimens between parentheses. Oneway ANOVA results are presented.

reservoir are probably consequence from the stages of gonadal development selected for the analysis (resting and spent) In this species, spent males may present greater energy in the muscles than spent females because their energetic investment in production of gametes is lower during the reproductive process (gonad maturation and maintenance). These males, after spawning, may allocate the energy stored in the muscles to sexual dimorphism and parental care (elongation of labium to carry and protect eggs and larvae) (Isbrücker \& Nijssen, 1979; Dei Tos et al., 1997; Nakatani et al., 2001; Marcucci et al., 2005). Probably, the males sampled in Rosana Reservoir had not yet mobilized the energy from their muscles for such activities, whereas in the floodplain and in the stream, this mobilization could have already been started, which resulted in the absence of energetic difference between the sexes, even using only these two developmental stages.

The use of equivalent stages to make comparisons between sexes and in the three locations (resting and spent) emerged as an alternative to identify some pattern among the sites, regarding the variation in muscle density between the sexes. Comparisons using different stages would lead to wrong conclusions.

The variation in muscle energy density during the repro-
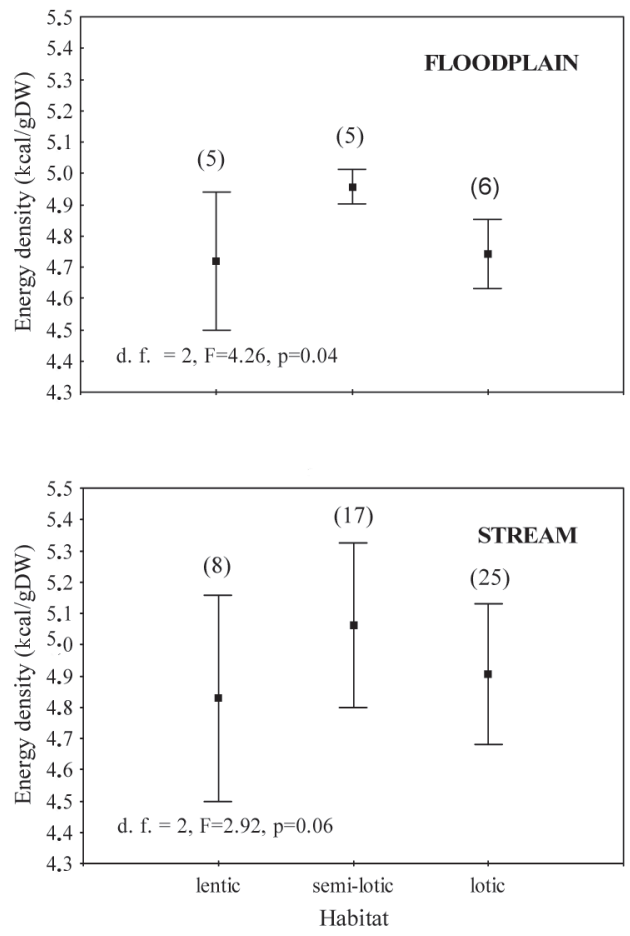

Fig. 4. Mean \pm standard deviation energy density of Loricariichthys platymetopon of both the sexes and same gonadal development stages (resting or spent) for type of habit sampled in the upper Paraná River floodplain and Diamante Stream. Number of specimens between parentheses. One-way ANOVA test.

ductive process may be associated to the energy transference from the muscles to the gonads and to spawning, and the absence of such variation is due to the use of energy stored as visceral fat (Doria \& Andrian, 1997; Encina \& Granado-Lorencio, 1997; Jonsson et al. 1997). Both sexes from species of tropical fishes are able to accumulate visceral fat and, depending on the environmental conditions to which they are submitted, they may accumulate more or less fat, as well as use them or not.

The variation in muscle energy density of $L$. platymetopon related to different gonadal development stages was observed for males, in the upper Paraná River floodplain, and for both sexes at the Rosana Reservoir, but absent in Diamante Stream.

In the Manso Reservoir and adjacent area, this variation was recorded only for males of $S$. marginatus, $S$. maculatus and Brycon hilarii (Characidade), while, for H. edentatus, such variation was not verified in any sex (Santos et al., 2006; Monteiro et al., 2007). Doria \& Andrian (1997) verified the absence of this variation, in a study accomplished only with females of Schizodon borelli (Anostomidae) and Pimelodus maculatus (Pimelodidae) in floodplain above mentioned.

Considering all sites, spatial variation was recorded in the muscle energy density of L. platymetopon, with the highest mean energy recorded at the Rosana Reservoir. Santos et al. 
(2006) also observed differences between specimens of $S$. maculatus from a reservoir (Manso Reservoir) and its adjacent area (males and females as well), with a higher mean energetic density in the reservoir and tributaries when compared to local bay habitats. However, this spatial variation was not detected for S. marginatus, Leporinus friderici, Acestrorhynchus pantaneiro, and Schizodon borelli in same study area (Santana et al., 2005).

A possible cause for the higher energetic values found at the Rosana Reservoir could be its lower water flow when compared to the other locations. In a lentic habitat, the energy expenditures of the fish with swimming (maintenance of position in the water or movement against flow $t$ ) are lower than in lotic habitats (Wootton, 1990; Rosenfeld \& Boss, 2001).

Another factor that possibly influences the variation in muscle energy density of L. platymetopon, may be the spatial variation in detritus quality and quantity. According to Moore et al. (2004), these factors may be distinct among the systems, and represent primary factors on the distribution of energy for the various physiological processes of fish. If quality and quantity of detritus are high, and if the food intake rate is sufficiently high, the fish are able to grow, produce gametes or store products (Adams et al., 1982; Wootton, 1990; Moore et al., 2004), therefore explaining, partially, the higher energetic mean recorded for Rosana Reservoir, because the lower current flow can also lead to greater accumulation of detritus on sediment. This idea is corroborated by Melo (2006), in rivers (lotic and semi-lotic) of the upper Paraná River floodplain, and by Gimenes et al. (2004) in open lagoons, channel and rivers in the same floodplain. According to these studies, the percentage of organic matter on the sediment (detritus) is greater in lentic and semi-lotic habitats than in lotic habitats.

Thus, it can be concluded that the variation in muscle energy density of L. platymetopon may occur and be related to sex, gonadal development stages and site. Meantime, the variation between the sexes may or may not occur depending on the site, and the occurrence of variation in density among the stages seems to be dependent on both the site and the sex analyzed. The spatial variation in energy density of $L$. platymetopon recorded in this study strengthen the idea that this factor is not an invariable parameter and should not be applied in bioenergetics modeling and in the quantification of energetic balance as an unique value.

Research focusing the intraspecific variation in energy density from tropical fish species need to be intensified and expanded for a greater number of species, only then it will be possible to effectively determine patterns as well as identify and explain them in posterior studies. Nevertheless, in order to prevent the determination of wrong patterns or the development of erroneous hypotheses, future studies must encompass the samplings of both sexes and the largest possible number of gonadal development stages, instead of randomly determining a sample size or analyzing only one gonadal stage.

\section{Acknowledgements}

The authors thank to Cnpq/Capes/UEM for financial and logistic support. To everyone who helped in field and laboratory work (Peld, Pronex and Caiuá Projects-UEM/Nupelia). To the Post-Graduation Course in Ecology of Continental Aquatic Environments (PEA-UEM). To Capes for the Master's degree scholarship. To Jaime Luiz L. L. Pereira for the map elaboration and to Maria S. R. Arita, João F. Hildebrandt and Márcia Regina Paiva for the help in bibliography review. To Dayani Bailly and Lorena T. Oporto for reading the manuscript.

\section{Literature Cited}

Adams, S. M., R. B. McLean \& J. A. Parrota. 1982. Energy partitioning in largemouth bass under conditions of seasonally fluctuating prey availability. Transactions of the American Fisheries Society, 111: 549-558.

Bryan, S. D., C. A. Soupir, W. G. Duffy \& C. E. Freiburger. 1996. Caloric densities of three predatory fishes and their prey in Lake Oahe, South Dakota. Journal of Freshwater Ecology, 11(2): 153-161.

Dei Tos, C., A. A. Agostinho \& H. I. Suzuki. 1997. Population structure and reproductive biology of Loricariichthys platymetopon (Siluriformes, Pisces) in the upper river Paraná. Brazilian Archives of Biology and Technology, 40(4): 793-807.

Doria, C. R. \& I. F. Andrian. 1997. Variation in energy content of somatic and reproductive, tissues related to the reproductive cycle and feeding of female Pimelodus maculatus Lacépède, 1803 (Siluriformes, Pimelodidae) and Schizodon borellii Boulenger, 1895 (Characiformes, Anostomidae). Revista Unimar, 19(2): 421-437.

Dourado, E. C. dos S. \& E. Benedito-Cecilio. 2005. Ecologia energética de peixes: influência de fatores abióticos e bióticos. Maringá, Eduem, 53p.

Economidis, P. S., J. Pantis \& N. S. Margaris. 1981. Caloric content in some freshwater and marine fishes from Greece. Cybium, 5(4): 97-100.

Encina, L. \& C. Granado-Lorencio. 1997. Seasonal variations in the physiological status and energy content of somatic and reproductive tissues of chub. Journal of Fish Biology, 50: 511-522.

Fugi, R., A. A. Agostinho \& N. S. Hahn. 2001. Trophic morfology of five benthic-feeding fish species of a tropical floodplain. Revista Brasileira de Biologia, 61(1): 27-33.

Gaspar da Luz, K. D., E. F. Oliveira, A. C. Petry, H. F. Júlio Júnior, C. S. Pavanelli \& L. C. Gomes. 2004. Fish assemblages in the Upper Paraná River floodplain. Pp. 107-115. In: Agostinho, A. A., L. Rodrigues, L. C. Gomes, S. M. Thomaz \& L. E. Miranda (Eds.). Structure and functioning of the Paraná River and its floodplain: LTER - site 6. Maringá, Eduem, $275 \mathrm{p}$.

Gimenes, M. de F., E. Benedito-Cecilio, A. M. Takeda \& M. R. Vismara. 2004. Availability of sedimentary organic matter for benthic fishes of the upper Paraná river floodplain. Acta Scientiarum. Biological Sciences, 26(2): 181-187.

Gotelli, N. J. \& G. L. Entsminger. 2006. EcoSim: Null models software for ecology. Version 7. Acquired Intelligence Inc. \& Kesey-Bear. Jericho, VT 05465. Available at: http:// garyentsminger.com/ecosim.htm. Accessed Feb 25, 2008. 
Hansen, M. J., D. Boisclair, S. B. Brandt, S. W. Hewett, J. F. Kitchell, M. C. Lucas \& J. J. Ney. 1993. Applications of bioenergetics models to fish ecology and management: Where do we go from here? Transactions of the American Fisheries Society, 122: 1019-1030.

Isbrücker, I. J. H. \& H. Nijssen. 1979. Three new south american mailed catfishes of the genera Rineloricaria and Loricariichthys (Pisces, Siluriformes, Loricariidae). Bijdr, 48(2): 151-211.

Jonsson, N., B. Jonsson \& L. P. Hansen. 1997. Changes in proximate composition and estimates of energetic costs during upstream migration and spawning in Atlantic salmon Salmo salar. Journal of Animal Ecology, 66: 425-436.

Luiz, E. A., A. C. Petry, C. S. Pavanelli, H. F. Júlio Jr., J. D. Latini \& V. M. Domingues. 2005. As Assembleias de Peixes de Reservatórios Hidrelétricos do Estado do Paraná e Bacias Limítrofes. Pp. 170-184. In: Rodrigues, L., S. M. Thomaz, A. A. Agostinho \& L. C. Gomes (Orgs.). Biocenoses em reservatórios: padrões espaciais e temporais. São Carlos, Rima, 321p.

Marcucci, K. M. I., M. L. Orsi \& O. A. Shibatta. 2005. Abundância e aspectos reprodutivos de Loricariichthys platymetopon (Siluriformes, Loricariidae) em quatro trechos da represa Capivara, médio rio Paranapanema. Iheringia, Série Zoologia, 95(2): 197-203.

Melo, S. M. de. 2006. Os desconhecidos canais da planície aluvial do alto rio Paraná: a resposta ecológica das ninfas de Ephemeroptera. Unpublished Ph. D. Dissertation, Universidade Estadual de Maringá, Maringá, 44p.

Monteiro, V., E. Benedito \& W. M. Domingues. 2007. Efeito da estratégia de vida sobre as variações no conteúdo de energia de duas espécies de peixes (Brycon hilarii e Hypophthalmus edentatus), durante o ciclo reprodutivo. Acta Scientiarum. Biological Sciences, 29(2): 151-159.

Moore, J. C., E. L. Berlow, D. C. Coleman, P. C. de Ruiter, Q. Dong, A. Hastings, N. C. Johnson, K. S. McCann, K. Melville, P. J. Morin, K. Nadelhoffer, A. D. Rosemond, D. M. Post, J. L. Sabo, K. M. Scow, M. J. Vanni \& D. H. Wall. 2004. Detritus, trophic dynamics and biodiversity. Ecology Letters, 7: 584600.

Morales, B. F., E. Benedito \& E. F. de Oliveira. 2009b. Composição e estrutura da ictiofauna. Pp. 85-105. In: Benedito, E. (Org.). Ecologia do ribeirão Diamante: Estação Ecológica do Caiuá, PR. Maringá, Eduem, 168p.

Morales, B. F., C. C. de O. Ramos \& E. Benedito. 2009a. Os desafios do Ribeirão Diamante na Estação Ecológica do Caiuá. Pp. 15-26. In: Benedito, E. (Org.). Ecologia do ribeirão Diamante: Estação Ecológica do Caiuá, PR. Maringá, Eduem, 168p.
Nakatani, K., A. A. Agostinho, G. Baumgartner, A. Bialetzki, P. V. Sanches, M. C. Makrakis \& C. S. Pavanelli. 2001. Ovos e larvas de peixes de água doce: desenvolvimento e manual de identificação. Maringá, Eduem, 378p.

Paul, A. J., J. M. Paul \& E. D. Brown. 1998. Fall and spring somatic energy content for Alaskan Pacific herring (Clupea pallasi Valenciennes 1847) relative to age, size and sex. Journal of Experimental Marine Biology and Ecology, 223: 133-142.

Pedersen, J. \& J. R. G. Hislop. 2001. Seasonal variation in the energy density of fishes in the North Sea. Journal of Fish Biology, 59(2): 380-389.

Querol, M. V. M., E. Querol \& N. N. A. Gomes. 2002. Fator de condição gonadal, índice hepatossomático e recrutamento como indicadores do período de reprodução de Loricariichthys platymetopon (Osteichthyes, Loricariidae), bacia do rio Uruguai médio, sul do Brasil. Iheringia, Série Zoologia, 92(3): 79-84.

Reis, R. E., S. O. Kullander \& C. J. Ferraris Jr (Org.). 2003. Check list of the freshwater fishes of South and Central America. Porto Alegre, Edipucrs, 742p.

Rodrigues, L., S. M. Thomaz, A. A. Agostinho \& L. C. Gomes (Orgs.). 2005. Biocenoses em reservatórios: padrões espaciais e temporais. São Carlos, Rima, 321p.

Rosenfeld, J. S. \& S. Boss. 2001. Fitness consequences of habitat use for juvenile cutthroat trout: energetic costs and benefits in pools and riffles. Canadian Journal of Fisheries and Aquatic Sciences, 58(3): 585-593.

Santana, A. R. A., E. Benedito-Cecilio \& W. M. Domingues. 2005. Conteúdo energético de peixes do reservatório do rio Manso: variações espaciais e por grupo trófico. Acta Scientiarum. Biological Sciences, 27(4): 391-395.

Santos, M. H. dos, E. Benedito-Cecilio \& W. M. Domingues. 2006. Efeito da maturação gonadal sobre a energia dos músculos de duas espécies de piranhas do reservatório do rio Manso, MT. Acta Scientiarum, Biological Sciences, 28: 227-236.

Vazzoler, A. E. A. de M. 1996. Biologia da reprodução de peixes teleósteos: teoria e prática. Maringá, Eduem: Nupelia, 169p.

Vazzoler, A. E. A., A. A. Agostinho \& N. S. Hahn (Eds.). 1997. A planície de inundação do alto rio Paraná: aspectos físicos, biológicos e socioeconômicos. Maringá, Eduem, 460p.

Vismara, M. R., E. Benedito-Cecilio \& A. C. E. A. Faria. 2004. Efeito da maturação gonadal sobre o conteúdo calórico e condição geral de peixes da planície de inundação do alto rio Paraná. Acta Scientiarum, Biological Sciences, 26(2): 189-199.

Wootton, R. J. 1990. Growth. Pp.117-158. In: Wootton, R. J. (Ed.). Ecology of teleost fishes. London, Chapman \& Hall, 404p. 